\title{
ANALISIS EFEKTIVITAS PENGGUNAAN KARTU TANI DI EKS-KARESIDENAN PATI
}

\section{(Analysis Of The Effectiveness Of The Use Of Farmer Card In Pati Eks-Residency)}

\author{
Mesiastri Prisnia Isabella ${ }^{1}$ dan Lasmono Tri Sunaryanto ${ }^{2}$ \\ Program Studi Agribisnis, Fakultas Pertanian dan Bisnis Universitas Kristen Satya Wacana \\ Jalan Diponegoro 52-60 Salatiga 50711, Jawa Tengah - Indonesia \\ Telp. (0298) 321212, 7104058, Faks. (0298) 324043 \\ email: mesiastriisabella@gmail.com ${ }^{1}$,lasmono@staff.uksw.edu ${ }^{2}$
}

Article Submitted : 12-5-2020

Article Accepted : 03-6-2020

\begin{abstract}
The aim of this study is 1) to analyze the effectiveness of the use of farmer card in Pati Eks-Caresident, 2) to identify obstacle factors, which affect the effectiveness of the use of farmer card in Pati Eks-Residency. The selection of locations is to use multistage purposive sampling and simple random sampling. Multistage purposive sampling to determine the regency and simple random sampling to determine the district and village. The study involves a mixed method that is the method of merging quantitative and qualitative methods. The research variable is the success of the program (X1), the success of targets (X2), and the satisfaction of programs (X3). The result of this study is the success of the program, the success of targets, and the satisfaction of programs affect significantly the effectiveness of the use of farmer card in Pati Eks-Residency.
\end{abstract}

Keywords: Effectiveness analysis, farmer card

\section{PENDAHULUAN}

Pupuk sangat dibutuhkan untuk meningkatkan hasil produktivitas pertanian. Dalam pendistribusian pupuk seringkali terjadi harga pupuk yang tidak stabil, sehingga pemerintah memberi subsidi berupa pupuk bersubsidi. Pupuk bersubsidi sangat diperhatikan dan diawasi oleh pemerintah dalam pendistribusian di setiap daerah. Pemerintah menyediakan pupuk bersubsidi seperti urea, SP 36, ZA, NPK dan Organik. Pada kenyataanya, sering ditemui berbagai masalah seperti kelangkaan pupuk bersubsidi.

Menurut Ardiyanto \& Santoso (2013), kelangkaan pupuk bersubsidi disebabkan adanya peningkatan penggunaan pupuk dan terbatasnya pengecer atau penjual di suatu daerah. Tak hanya itu, seringkali juga ditemukan keterbatasan persediaan pupuk, sehingga harga pupuk menjadi meningkat. Harga Eceran Tertinggi dan Harga yang ada di lapangan merupakan salah satu masalah yang sering terjadi dikalangan masyarakat. Pemerintah Provinsi Jawa Tengah bekerjasama dengan BRI (Bank Rakyat Indonesia) untuk menghadirkan kartu tani. Kartu tani berguna untuk mengalokasikan pupuk bersubsidi bagi masyarakat khususnya petani. Dalam pendistribusian pupuk bersubsidi, kartu tani berlandasan pada enam asas yaitu tepat harga, tepat mutu, tepat jumlah, tepat waktu, tepat lokasi, dan tepat jenis. 
Faktor yang mempengaruhi petani dalam pemakaian pupuk antara lain: ketersediaan pupuk di pasaran, kemudahan petani mendapatkan pupuk, dan kemampuan petani dalam membeli pupuk (Moko et al., 2018)

Kartu tani merupakan layanan yang disediakan pemerintah untuk petani yang berkerjasama dengan layanan perbankan yang berfungsi sebagai simpanan,transaksi, penyaluran pinjaman, dan kartu subsidi pupuk. Kartu tani ini berisi Rencana Definitif Kebutuhan Kelompok (RDKK) yang berisi data anggota kelompok tani yaitu luasan lahan yang digarap maksimal 2 (dua) hektar, jenis tanaman dan alokasi pupuk. Kartu tani ini digunakan untuk menebus pupuk bersubsidi dimana transaksi penebusannya menggunakan mesin Electronic Data Capture (EDC) yang ada ditempat pengecer pupuk. Pada saat petani menebus pupuk bersubsidi kepada pengecer, maka secara otomatis akan mengurangi alokasi pupuk bersubsidi dan saldo dalam kartu tani akan berkurang (Kurniawati \& Kurniawan, 2018).

Menurut Badan Penyuluh dan Pengembangan SDM Pertanian (2017) dalam Sholihah \& Djamaludin, (2018), kartu tani merupakan kartu yang dapat mengakses berbagai kegiatan seperti simpanan, transaksi, penyaluran kredit dan pendistribusian pupuk bersubsidi. Oleh karena itu, kartu tani diharapkan dapat menyelesaikan permasalahan di tingkat petani khususnya terhadap kelangkaan pupuk bersubsidi.

Banyak petani yang belum menggunakan kartu tani dengan baik, sehingga implementasi dari kartu tani belum dapat berjalan secara optimal. Sejalan dengan permasalahan tersebut, perlu dilakukan penelitian untuk melakukan analisis efektivitas penggunaan kartu tani di Eks-Karesidenan Pati. Secara lebih khusus, penelitian ini ingin mengetahui seberapa efektif penggunaan kartu tani di EksKaresidenan Pati.

\section{METODE PENELITIAN}

Lokasi penelitian dilakukan di EksKaresidenan Pati dengan mengambil tiga kabupaten/kota yaitu Kabupaten Pati di Kecamatan Jakenan, Kabupaten Kudus di Kecamatan Undaan, dan Kabupaten Rembang di Kecamatan Sumber. Waktu penelitian dilakukan mulai bulan Januari 2020.

Jenis penelitian ini menggunakan deskriptif kuantitatif. Menurut Sugiyono, (2018), metode kuantitatif digunakan untuk meneliti pengumpulan data dengan alat penelitian, populasi atau sampel tertentu, dan untuk menguji hipotesis yang telah ditetapkan.

Teknik pengambilan sampel yang digunakan pada penelitian ini yaitu Multistage Purposive Sampling dan Simple Random Sampling. Multistage Purposive sampling digunakan karena populasi mencakup wilayah yang luas. Penarikan sampel tidak dilakukan secara langsung ke elemennya tetapi harus di cluster terlebih dahulu. Pada tahap cluster ini, tidak dipilih semua elemennya namun akan dipilih berdasarkan kriteria yang ditentukan oleh peneliti berdasarkan tujuan penelitian. Kriteria-kriteria sampel yang ditentukan yaitu : a.memiliki kartu tani dan menggunakan, b.tergabung dalam kelompok tani.

Simple random sampling merupakan pengambilan sampel secara acak dari populasi dengan tidak memperhatikan strata pada populasi tersebut Sugiyono, (2013). Tahap pertama yang dilakukan adalah memilih 3 kabupaten dari 5 kabupaten yang ada di eks-karesidenan. Tahap kedua, pada 3 kabupaten terpilih, dipilih 3 kecamatan dari 44 kecamatan yang ada di 3 kabupaten. Pengambilan sampel ini menggunakan metode multistage purposive sampling. Untuk pemilihan desa, peneliti menggunakan metode simple random sampling dari kecamatan yang telah ditentukan sebelumnya. Jumlah sampel yang akan diteliti sebanyak 50 responden yang 
diambil dari 3 kabupaten. Untuk menilai seberapa efektif tanggapan responden terhadap indikator variabel dapat dilihat pada tabel kriteria penilaian efektivitas:

Tabel 1. Kriteria penilaian efektivitas

\begin{tabular}{lc}
\hline Persentase $(\%)$ & Penilaian \\
\hline $0-20$ & Sangat tidak efektif \\
$21-40$ & Tidak efektif \\
$41-60$ & Cukup efektif \\
$61-80$ & Efektif \\
$81-100$ & Sangat efektif \\
\hline
\end{tabular}

Sumber: (Riduwan, 2007)

Efektivitas penggunaan kartu tani digunakan rumus regresi linear berganda menurut Arikunto (2013) adalah:

Model regresi linear berganda:

$\mathrm{Y}=\mathrm{b}_{0}+\mathrm{b}_{1} \mathrm{X}_{1}+\mathrm{b}_{2} \mathrm{X}_{2}+\mathrm{b}_{3} \mathrm{X}_{3}+\mathrm{e}$

$\mathrm{Y}=$ Efektivitas penggunaan kartu tani

$\mathrm{X}_{1}=$ Keberhasilan program

$\mathrm{X}_{2}=$ Keberhasilan sasaran

$\mathrm{X}_{3}=$ Kepuasan terhadap program

$\mathrm{e}=$ error

Uji hipotesis penelitian menggunakan

uji $\mathrm{F}$, uji $\mathrm{t}$ dan koefisien determinasi $\left(\mathrm{R}^{2}\right)$ dijelaskan sebagai berikut :

1. Uji F

Uji $\mathrm{F}$ digunakan untuk menunjukkan jika semua variabel independen yang dikaitkan berpengaruh secara bersama-sama terhadap variabel dependen (Ghozali, 2016). Pengambilan keputusan menurut Priyatno, (2013) :

a. Jika F hitung $\leq \mathrm{F}$ tabel maka Ho diterima Jika $\mathrm{F}$ hitung $>\mathrm{F}$ tabel maka Ho ditolak b. Jika probabilitas $>0,05$ maka Ho diterima Jika probabilitas $\leq 0,05$ maka Ho ditolak 2.Uji t

Uji $\mathrm{t}$ digunakan untuk mengetahui pengaruh satu variabel independent terhadap variabel independent lainnya. Pengambilan keputusan menurut Priyatno, (2013) yaitu : a. Jika $t$ hitung $<\mathrm{t}$ tabel, maka Ho diterima Jika thitung $>\mathrm{t}$ tabel, maka Ho ditolak b. Jika probabilitas $>0,05$ maka Ho diterima Jika probabilitas $<0,05$ maka Ho ditolak

3. Koefisien Determinasi $\left(\mathrm{R}^{2}\right)$

Koefisien determinasi $\left(\mathrm{R}^{2}\right)$ digunakan untuk mengukur seberapa jauh pengaruh variabel independen dalam menjelaskan varians terhadap variabel terikatnya. Nilai koefisien determinasi yaitu antara nol sampai satu $\left(0<R^{2}>1\right)$. Nilai koefisien determinasi ditentukan dengan nilai adjusted $R$ square atau nilai $\mathrm{R}^{2}$ yang mendekati satu, maka model regresi dianggap semakin baik karena variabel bebasnya mampu menjelaskan variabel terikatnya (Priyatno, 2013)

\section{HASIL DAN PEMBAHASAN}

\section{Karakteristik Responden}

\section{Jenis Kelamin}

Berdasarkan jenis kelamin responden dalam penelitian ini dapat dilihat pada tabel dibawah ini :

Tabel 2. Responden Berdasarkan Jenis Kelamin

\begin{tabular}{lccc}
\hline Kabupaten & Laki-laki & Perempuan & Persentase $(\%)$ \\
\hline Pati & 13 & 2 & $30 \%$ \\
Kudus & 13 & 0 & $26 \%$ \\
Rembang & 16 & 6 & $44 \%$ \\
Total & 42 & 8 & $100 \%$ \\
\hline
\end{tabular}

Sumber : Data Primer diolah, (2020) 
Berdasarkan tabel jenis kelamin responden diatas, dapat diketahui bahwa responden laki-laki kabupaten pati sebanyak 13 orang, di kabupaten kudus sebanyak 13 orang, kabupaten rembang sebanyak 16 orang dan responden perempuan kabupaten pati sebanyak 2 orang, kabupaten kudus tidak ada dan kabupaten rembang sebanyak 6 orang. Sebagian besar responden dalam penelitian ini adalah laki-laki.

2. Usia

Berdasarkan usia responden dalam penelitian ini dapat dilihat pada table 3 .

Tabel 3. Responden Berdasarkan Usia

\begin{tabular}{lcccc}
\hline Kabupaten & $29-48$ & $49-68$ & $69-88$ & Persentase (\%) \\
\hline Pati & 3 & 11 & 1 & $30 \%$ \\
Kudus & 3 & 9 & 1 & $26 \%$ \\
Rembang & 12 & 9 & 1 & $44 \%$ \\
Total & 18 & 29 & 3 & $100 \%$ \\
\hline
\end{tabular}

Sumber: Data Primer diolah, (2020)

Berdasarkan tabel usia responden diatas, dapat diketahui bahwa responden di. Responden di kabupaten pati dengan usia 29-48 sebanyak 3 orang,responden dengan usia 49-68 sebanyak 11 orang dan responden dengan usia 69-88 sebanyak 1 orang, kabupaten kudus dengan usia 29-48 sebanyak 3 orang,responden dengan usia 4968 sebanyak 9 orang dan responden dengan usia 69-88 sebanyak 1 orang, responden di kabupaten rembang dengan usia 29-48 sebanyak 12 orang,responden dengan usia 49-68 sebanyak 9 orang dan responden dengan usia 69-88 sebanyak 1 orang. Sebagian besar responden dalam penelitian ini adalah berusia 49-68.

\section{Tingkat Pendidikan}

Berdasarkan tingkat pendidikan responden dalam penelitian ini dapat dilihat pada tabel berikut :

Tabel 4. Responden Berdasarkan Tingkat Pendidikan

\begin{tabular}{lccccccc}
\hline Kabupaten & $\begin{array}{c}\text { Tidak } \\
\text { Sekolah }\end{array}$ & SD & SMP & SMA & S1 & S2 & $\begin{array}{c}\text { Persentase } \\
(\%)\end{array}$ \\
\hline Pati & 0 & 7 & 2 & 3 & 3 & 0 & $30 \%$ \\
Kudus & 1 & 9 & 0 & 2 & 0 & 1 & $26 \%$ \\
Rembang & 0 & 14 & 7 & 1 & 0 & 0 & $44 \%$ \\
\hline \multicolumn{1}{c}{ Total } & 1 & 30 & 9 & 6 & 3 & 1 & $100 \%$ \\
\hline
\end{tabular}

Sumber: Data Primer diolah, (2020)

Berdasarkan tabel tingkat pendidikan diatas, dapat diketahui bahwa responden di kabupaten pati yang tidak sekolah tidak ada, SD sebanyak 7 orang, SMP sebanyak 2 orang, SMA sebanyak 3 orang, S1 sebanyak 3 orang dan S2 tidak ada, responden kabupaten kudus yang tidak sekolah sebanyak 1 orang,SD sebanyak 9 orang, SMP tidak ada, S1 tidak ada, dan S2 sebanyak 1, responden di kabupaten rembang yang tidak sekolah tidak ada, SD sebanyak 14 orang, SMP sebanyak 7 orang, SMA sebanyak 1 orang, S1 tidak ada dan S2 tidak ada. Sebagian besar responden dalam penelitian ini memiliki tingkat pendidikan SD.

4. Berdasarkan Status Kepemilikan

Berdasarkan status kepemilikan 
responden dalam penelitian ini dapat dilihat

pada tabel berikut :

Tabel 5. Responden Berdasarkan Status Kepemilikan

\begin{tabular}{lcccc}
\hline Kabupaten & $\begin{array}{c}\text { Milik } \\
\text { Sendiri }\end{array}$ & Menyewa & Bengkok & Persentase (\%) \\
\hline Pati & 12 & 1 & 2 & $30 \%$ \\
Kudus & 12 & 1 & 0 & $26 \%$ \\
Rembang & 22 & 0 & 0 & $44 \%$ \\
\hline \multicolumn{1}{c}{ Total } & 46 & 2 & 2 & $100 \%$ \\
\hline
\end{tabular}

Sumber: Data primer diolah, (2020)

Berdasarkan tabel status kepemilikan diatas, dapat diketahui bahwa responden di kabupaten pati dengan status kepemilikan milik sendiri sebanyak 12 orang, menyewa 1 orang dan bengkok 2 orang, responden di kabupaten kudus dengan status kepemilikan milik sendiri sebanyak 12 orang, menyewa 1

\section{Keberhasilan Program}

Tabel 6. Keberhasilan Program orang dan bengkok tidak ada, responden di kabupaten rembang dengan status kepemilikan milik sendiri sebanyak 22 orang. Sebagian besar responden dalam penelitian ini berdasarkan status kepemilikan adalah milik sendiri.

\begin{tabular}{clcc}
\hline No & \multicolumn{1}{c}{ Pernyataan } & Persentase $(\%)$ & Kategori \\
\hline 1. & $\begin{array}{l}\text { Saya mudah mendapatkan } \\
\text { pupuk melalui Kartu Tani }\end{array}$ & 66 & Cukup efektif \\
2. & $\begin{array}{l}\text { Saya mudah menabung melalui } \\
\text { Kartu Tani }\end{array}$ & 49,2 & Tidak efektif \\
\hline & Total & 57,6 & Cukup efektif \\
\hline
\end{tabular}

Sumber: Data Primer diolah, (2020)

Berdasarkan tabel keberhasilan program diatas diperoleh pernyataan pertama lebih tinggi persentasenya dengan kategori cukup efektif. Hal ini dikarenakan responden merasa mudah mendapatkan pupuk melalui kartu tani karena sudah ditetapkan jatah pupuk yang akan didapat. Selain itu, responden merasa lebih aman karena jatah pupuk yang ada di pengecer tidak dapat diberikan kepada sembarang orang tanpa menunjukkan kartu tani atau KTP. Sedangkan pada pernyataan kedua lebih rendah persentasenya dengan kategori tidak efektif. Hal ini karena responden merasa bahwa program kartu tani ini belum terlalu jelas tujuannya. Selain itu responden juga merasa ribet jika harus menyetor uang dulu di bank dengan alasan tidak ada waktu maupun tidak dapat menggunakan kendaraan sendiri. Dilihat dari total keberhasilan program dapat disimpulkan bahwa keberhasilan program sudah cukup efektif dilakukan. 


\section{Keberhasilan Sasaran}

Tabel 7. Keberhasilan sasaran

\begin{tabular}{lcc}
\hline \multicolumn{1}{c}{ Pernyataan } & Persentase (\%) & Kategori \\
\hline Terbantu dengan penyediaan pupuk yang tepat tempat & 70,4 & Efektif \\
Terbantu dengan penyediaan pupuk yang tepat harga & 59,6 & Cukup efektif \\
Terbantu dengan penyediaan pupuk yang tepat jenis & 70 & Efektif \\
Terbantu dengan penyediaan pupuk yang tepat jumlah & 47,6 & Cukup efektif \\
Terbantu dengan penyediaan pupuk yang tepat waktu & 62,8 & Efektif \\
Terbantu dengan penyediaan pupuk yang tepat mutu & 69,6 & Efektif \\
\hline Total & 63,33 & Efektif \\
\hline
\end{tabular}

Sumber: Data Primer diolah, (2020)

Berdasarkan tabel keberhasilan sasaran diatas diperoleh bahwa pernyataan pertama lebih tinggi persentasenya dengan kategori efektif. Hal ini dikarenakan responden merasa tidak ada masalah dengan tempat penyediaan pupuk atau tempat pengecer, karena letak pengecer yang berada ditengahtengah artinya tidak terlalu jauh maupun terlalu dekat. Sedangkan pada pernyataan keempat lebih rendah persentasenya dengan kategori cukup efektif. Hal ini dikarenakan ada responden yang merasa bahwa jumlah pupuk subsidi yang diberikan oleh pemerintah masih kurang dan tidak sesuai dengan luas lahan yang di daftar kan di kartu tani dan ada juga responden yang merasa cukup dengan jumlah pupuk subsidi yang diberikan oleh pemerintah. Dilihat dari total keberhasilan sasaran dapat disimpulkan bahwa keberhasilan sasaran sudah efektif dilakukan.

\section{Kepuasan Terhadap Program}

Tabel 8. Kepuasan terhadap program

\begin{tabular}{lcc}
\hline \multicolumn{1}{c}{ Pernyataan } & Persentase (\%) & Kategori \\
\hline Terbantu dengan adanya kartu tani & 62,4 & Efektif \\
Kartu tani membantu dalam mendapatkan informasi & 54,8 & Cukup efektif \\
Kartu tani membantu meningkatkan produktivitas saya & 57,6 & Cukup efektif \\
Terbantu dengan adanya pengecer di desa & 76,8 & Efektif \\
Terbantu dengan adanya lokasi pengecer yang dekat dengan & 67,2 & Efektif \\
desa & & \\
Terbantu dengan adanya sarana dan prasarana yang dikelola & 62,8 & Efektif \\
oleh BRI & 59,2 & Cukup efektif \\
Terbantu dengan lokasi BRI yang dekat dengan desa & 62,97 & Efektif \\
\hline \multicolumn{1}{c}{ Total }
\end{tabular}

Sumber: Data primer diolah, (2020)

Berdasarkan tabel kepuasan terhadap program diatas diperoleh pernyataan keempat lebih tinggi persentasenya dengan kategori efektif. Hal ini dikarenakan responden merasa tidak ada masalah dengan pengecer di desa. Pengecer membantu responden dengan baik. Sedangkan pada pernyataan kedua lebih rendah persentasenya dengan kategori cukup efektif. Hal ini dikarenakan sebagian responden ada yang merasa kartu tani membantu dalam mendapatkan informasi dan ada juga sebagian responden merasa kartu tani tidak membantu dalam mendapatkan informasi. Dilihat dari total kepuasan terhadap program dapat 
disimpulkan bahwa kepuasan terhadap program sudah efektif dilakukan.

\section{Efektivitas Penggunaan Kartu Tani}

Tabel 9. Efektivitas penggunaan kartu tani

\begin{tabular}{lcc}
\hline \multicolumn{1}{c}{ Pernyataan } & $\begin{array}{c}\text { Persentase } \\
(\%)\end{array}$ & Kategori \\
\hline Kartu Tani berdampak pada kepastian pelaksanaan usahatani & 63,6 & Efektif \\
saya & 56,4 & Cukup efektif \\
Kartu tani berdampak pada peningkatan & 54 & Cukup efektif \\
Kartu tani berdampak pada peningkatan kualitas dan hasil & 58 & Cukup efektif \\
\hline panen & &
\end{tabular}

Sumber: Data primer diolah, (2020)

Berdasarkan tabel efektivitas penggunaan kartu tani diperoleh pernyataan pertama lebih tinggi persentasenya dengan kategori efektif. Hal ini dikarenakan responden merasa bahwa selama ada pupuk maka dapat berdampak pada pelaksanaan usahatani. Sedangkan pada pernyataan ketiga lebih rendah persentasenya dengan kategori cukup efektif. Hal ini dikarenakan

\section{Uji Analisis Regresi Linear Berganda}

Tabel 10. Uji regresi linear berganda ada responden yang merasa kartu tani kurang berdampak terhadap peningkatan kualitas dan hasil panen dan ada responden yang merasa kartu tani berdampak terhadap peningkatan kualitas dan hasil panen. Dilihat dari total efektivitas penggunaan kartu tani dapat disimpulkan bahwa efektivitas penggunaan kartu tani sudah cukup efektif dilakukan.

\begin{tabular}{lccc}
\hline \multicolumn{1}{c}{ Model } & $\mathrm{B}$ & $\mathrm{T}$ & $\mathrm{Sig}$ \\
\hline Constanta & $-0,733$ & $-0,498$ & 0,623 \\
Keberhasilan program & 0,847 & 3,869 & 0,001 \\
Keberhasilan sasaran & 0,499 & 6,531 & 0,000 \\
$\begin{array}{l}\text { Kepuasan terhadap } \\
\text { program }\end{array}$ & $-0,217$ & $-2,215$ & 0,035 \\
\hline
\end{tabular}

Sumber: Data primer diolah, (2020)

Berdasarkan pada tabel diatas dapat dituliskan model persamaan regresi sebagai berikut:

$\mathrm{Y}=-0,733+0,847 \mathrm{X} 1+0,499 \mathrm{X} 2-0,217 \mathrm{X} 3$

Pada persamaan regresi tersebut dapat dijelaskan sebagai berikut :

a. Koefisien konstanta efektivitas penggunaan kartu tani (Y) yaitu negatif 0,733. Artinya jika variabel independen dianggap konstant, maka efektivitas penggunaan kartu tani sebesar 0,733.

b. Koefisien regresi keberhasilan program sebesar 0,847 bernilai positif artinya jika variabel lain nilainya tetap dan keberhasilan program mengalami kenaikan sebesar satu satuan, maka efektivitas penggunaan kartu tani akan mengalami kenaikan sebesar 0,847 satuan.

c. Koefisien regresi keberhasilan sasaran sebesar 0,499 bernilai positif artinya jika variabel lain nilainya tetap dan keberhasilan sasaran mengalami kenaikan sebesar satu satuan, maka efektivitas penggunaan kartu tani akan mengalami kenaikan sebesar 0,499 satuan.

d. Koefisien regresi kepuasan terhadap 
program sebesar negatif 0,217 artinya jika variabel lain nilainya tetap dan kepuasan terhadap program mengalami kenaikan

\section{Uji F}

Tabel 11. Uji F sebesar satu satuan, maka efektivitas penggunaan kartu tani akan mengalami penurunan sebesar 0,217 satuan.

\begin{tabular}{lccccc}
\hline Model & Sum of & df & Mean Square & F & Sig. \\
\hline Squares & 201,851 & 3 & 67,284 & 36,213 & $0,000^{\mathrm{b}}$ \\
Regression & 52,024 & 28 & 1,858 & & \\
Total & 253,875 & 31 & & & \\
\hline
\end{tabular}

Sumber: Data primer diolah, (2020)

Berdasarkan hasil tabel uji $\mathrm{F}$ diketahui nilai $\mathrm{F}$ hitung sebesar 36,213 . Nilai Ftabel dengan $\mathrm{N} 1=29$ dan $\mathrm{N} 2=3$ yaitu 2,81 . Karena nilai Fhitung $>$ Ftabel pada tingkat signifikan $0,05(36,213>2,93)$ dan nilai signifikansi 0,000 lebih kecil dari 0,05, maka Ho ditolak sehingga dapat Berdasarkan hasil uji koefisien determinasi, dapat diketahui bahwa nilai Adjusted $R$ square sebesar 0,773 atau sama dengan artinya $77,3 \%$. Sedangkan nilai $\mathrm{R}^{2}$ ( $\mathrm{R}$ square) sebesar 0,795 atau sama dengan artinya $79,5 \%$ variabel efektivitas penggunaan kartu tani (Y) dapat dijelaskan

\section{Uji t}

Tabel 13. Uji t disimpulkan bahwa secara bersamasama(simultan) keberhasilan program, keberhasilan sasaran, dan kepuasan terhadap program berpengaruh signifikan terhadap efektivitas penggunaan kartu tani.

\section{Koefisien Determinasi $\left(\mathbf{R}^{\mathbf{2}}\right)$}

oleh variabel keberhasilan program $\left(\mathrm{X}_{1}\right)$, keberhasilan sasaran $\left(\mathrm{X}_{2}\right)$, dan kepuasan terhadap program $\left(\mathrm{X}_{3}\right)$. Sedangkan sisanya yaitu sebesar $20,5 \%$ dapat dijelaskan oleh variabel-variabel lainnya yang tidak digunakan pada penelitian ini.

\begin{tabular}{lccc}
\hline Model & B & T & Sig. \\
\hline Constant & $-0,733$ & $-0,498$ & 0,623 \\
Keberhasilan program & 0,847 & 3,869 & 0,001 \\
Keberhasilan sasaran & 0,499 & 6,531 & 0,000 \\
Kepuasan terhadap program & $-0,217$ & $-2,215$ & 0,035 \\
\hline
\end{tabular}

Sumber: Data primer diolah, (2020)

Berdasarkan pada tabel hasil uji t diatas, dapat diketahui seberapa jauh variabel keberhasilan program, keberhasilan sasaran, dan kepuasan terhadap program secara individual terhadap variabel efektivitas penggunaan kartu tani yaitu :

1. Pengaruh variabel keberhasilan program terhadap efektivitas penggunaan kartu tani
Ho = Secara parsial tidak ada pengaruh signifikan antara keberhasilan program dengan efektivitas penggunaan kartu tani

$\mathrm{Ha}=$ Secara parsial ada pengaruh signifikan antara keberhasilan program dengan efektivitas penggunaan kartu tani

Berdasarkan hasil uji t pada tabel 13 
dapat diketahui nilai t hitung keberhasilan program sebesar 3,869 dengan nilai signifikansi sebesar 0,001 . Nilai $t_{\text {tabel }}$ dengan $\mathrm{df}=29$ pada taraf signifikansi $5 \%$ yaitu 2,045 . Karena nilai $t_{\text {hitung }}<t_{\text {tabel }}$ pada taraf signifikansi 5\% (3,869> 2,045), maka Ho ditolak sehingga dapat disimpulkan bahwa secara parsial ada pengaruh signifikan antara keberhasilan program dengan efektivitas penggunaan kartu tani.

2. Pengaruh variabel keberhasilan sasaran terhadap efektivitas penggunaan kartu tani

Ho = Secara parsial tidak ada pengaruh signifikan antara keberhasilan sasaran dengan efektivitas penggunaan kartu tani

$\mathrm{Ha}=$ Secara parsial ada pengaruh signifikan antara keberhasilan sasaran dengan efektivitas penggunaan kartu tani

Berdasarkan hasil regresi pada tabel diatas dapat diketahui nilai $t$ hitung keberhasilan sasaran sebesar 6,532 dengan nilai signifikansi sebesar 0,000 . Nilai $t_{\text {tabel }}$ dengan $\mathrm{df}=29$ pada taraf signifikansi $5 \%$ yaitu 2,045. Karena nilai $t_{\text {hitung }}>t_{\text {tabel }}$ pada taraf signifikansi 5\% (6,532> 2,045), maka Ho ditolak sehingga dapat disimpulkan bahwa secara parsial ada pengaruh signifikan antara keberhasilan sasaran dengan efektivitas penggunaan kartu tani.

3. Pengaruh variabel kepuasan terhadap program dengan efektivitas penggunaan kartu tani

Ho = Secara parsial tidak ada pengaruh signifikan antara kepuasan terhadap program dengan efektivitas penggunaan kartu tani

$\mathrm{Ha}=$ Secara parsial ada pengaruh signifikan antara kepuasan terhadap program dengan efektivitas penggunaan kartu tani

Berdasarkan hasil regresi pada tabel diatas dapat diketahui nilai $t$ hitung kepuasan terhadap program sebesar -2,215 dengan nilai signifikansi sebesar 0,035 . Nilai $t_{\text {tabel }}$ dengan $\mathrm{df}=29$ pada taraf signifikansi $5 \%$ yaitu 2,045. Karena nilai $\mathrm{t}_{\text {hitung }}<\mathrm{t}_{\text {tabel }}$ pada taraf signifikansi $5 \%$
$(2,215>2,045)$, maka Ho ditolak sehingga dapat disimpulkan bahwa secara parsial berpengaruh negatif dan ada pengaruh signifikan antara kepuasan terhadap program dengan efektivitas penggunaan kartu tani.

\section{KESIMPULAN DAN SARAN}

\section{Kesimpulan}

Berdasarkan hasil penelitian mengenai efektivitas penggunaan kartu tani di ekskaresidenan pati, menunjukkan bahwa variabel keberhasilan $\operatorname{program}\left(\mathrm{X}_{1}\right)$, keberhasilan sasaran $\left(\mathrm{X}_{2}\right)$, dan kepuasan terhadap program $\left(\mathrm{X}_{3}\right)$ berpengaruh secara signifikan terhadap efektivitas penggunaan kartu tani karena memiliki signifikansi lebih besar dari 0,05. Hal ini menunjukkan bahwa efektivitas penggunaan kartu tani dipengaruhi oleh keberhasilan program, keberhasilan sasaran dan kepuasan terhadap program. Keberhasilan program, keberhasilan sasaran, dan kepuasan terhadap program di eks-karesidenan pati sudah cukup efektif dilakukan, sehingga dapat disimpulkan bahwa efektivitas penggunaan kartu tani di eks-karesidenan pati sudah baik.

\section{Saran}

Berdasarkan dari hasil penelitian mengenai efektivitas penggunaan kartu tani di Eks-Karesidenan Pati, dapat diberikan saran bagi pemerintah dalam pemberian kuota atau jumlah pupuk harus lebih disesuaikan dengan kebutuhan lahan petani, sehingga tidak menimbulkan kekecewaan petani terhadap adanya kartu tani.

\section{DAFTAR PUSTAKA}

Ardiyanto, W., \& Santoso, P. B. (2013). Kajian Pupuk Bersubsidi di Pekalongan (Studi Kasus di Kesesi). Semarang: Journal of economics.

Ghozali, Imam. (2016). Aplikasi Analisis Multivariate dengan Program IBM SPSS 23. Semarang: BPFE Universitas Diponegoro. 
Kurniawati, E., \& Kurniawan, A. (2018). Persepsi Masyarakat Terhadap Penggunaan Kartu Tani di Kabupaten Pati (Kasus di Desa Wotan dan Desa Pakem, Kecamatan Sukolilo).Yogyakarta: Jurnal Bumi Indonesia.

Moko, K. W., Suwarto, S., \& Utami, B. W. (2018). Perbedaan Persepsi Petani Terhadap Program Kartu Tani di Kecamatan Kalijambe Kabupaten Sragen. Solo: Journal of Sustainable Agriculture.

Priyatno, D. W. (2013). Mandiri Belajar Analisis Data dengan SPSS. Yogyakarta: Mediakom.
Riduwan. (2007). Skala Pengukuran Variabel-variabel Penelitian. Bandung: Alfabeta,.

Sholihah, M. M. atu, \& Djamaludin, M. D. (2018). Analisis Intention of Farmer Card Utiliization Using Theory of Planned Behavior. Bogor: Journal of Consumer Sciences.

Sugiyono. (2013). Metode Penelitian Pendidikan Pendekatan Kuantitaif, Kualitatif, dan R\&DSugiyono. Bandung: Alfabeta

Sugiyono. (2018). Metode Penelitian Kombinasi (mixed methods). Bandung: Alfabeta 